Highlands, I believe it to have been produced after the post. Old Red deformation of the region; probably long afterwards. In some places it may by accident agree with the Old Red floor; but as a whole it must differ from that floor, because the floor was generally deformed after the Old Red strata were laid on it. Such coincidence is against all probabilities. It is altogether unlikely that a peneplain of so ancient a date as Middle Palæozoic time should have stood nearly level and close to sea-level until so comparatively late a date as just before the uplift that allowed the erosion of the glens.

It may be noted that the peneplain of the Highlands is of more imperfect form, of more difficult recognition, and hence attended with more uncertainty in explanation, than various other uplifted and dissected peneplains that $I$ have seen: for example, that of the Ardennes and Hunsrück, or that of southern New England, or of western Pennsylvania and Virginia. The Scotch example must have been a rugged one at the best. Local study may perhaps identify certain peneplain areas that were well developed by the denudation that formed them when the region stood lower, and that are not yet altogether obliterated by the denudation that has been initiated since the region has risen to about its present height. The record of such a study I would gladly see. At the same time it might be possible to infer by what sort of uplift the peneplain gained its present order of altitude; whether by an arching, such as Hayes and Campbell have described for the uplifted peneplain of the southern Appalachians (Nat. Geogr. Mag., Washington, vi, 1894 , p. 63), or otherwise. It is perhaps to Scotch geographers rather than to Scotch geologists that one must look for a solution of this long-postponed problem; but the solution will be welcome whencesoever it comes.

Harvard Cnirersity, September, 1896.

W. M. Davis.

\title{
THE PARALLEL ROADS OF GLEN ROY.
}

SIR,-If the "parallel roads" are marine raised beaches, they were accumulated between daily tide-marks, and as such are sure to differ in character from beaches accumulated at more or less fixed levels. Secondly, if the beaches were marine and rocky, one or other form of Littorina could scarcely be absent, and Littorinas are practically indestructible. In the loose sand of one at least of the Devonshire raised beaches, these shells occur in perfect preservation; Littorina obtusata is also said to occur in the deposits on Moel Tryfaen. If, then, the beach-deposits of the parallel roads of Glen Roy still survive, and no trace of Littorina can be found in them, the fact is hard to explain in such a sheltered valley, on the hypothesis that the accumulations are of marine origin. If, in addition to the absence of Littorina the beaches show no signs of being accumulated between tide-marks, the difficulty of accepting their marine origin will be greater still. The best evidence of a raised-beach platform is its sloping towards the water as part of an old tidal strand. Can such inclined planes be detected in the case of the parallel roads of Glen Roy?

A. K. Hunt. 


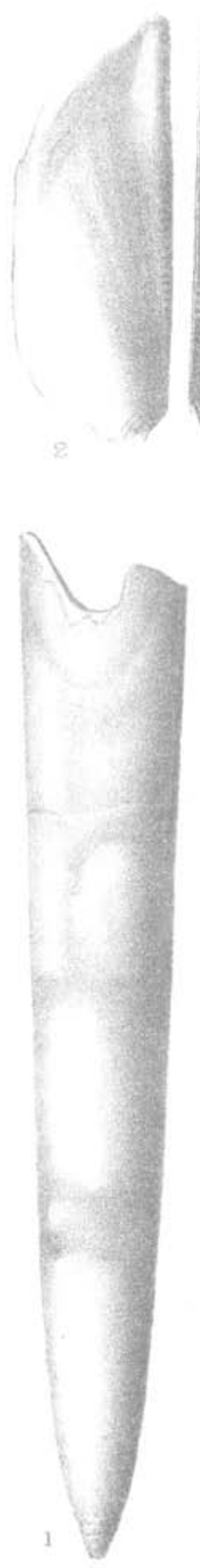

G.MWoocward del et hitin
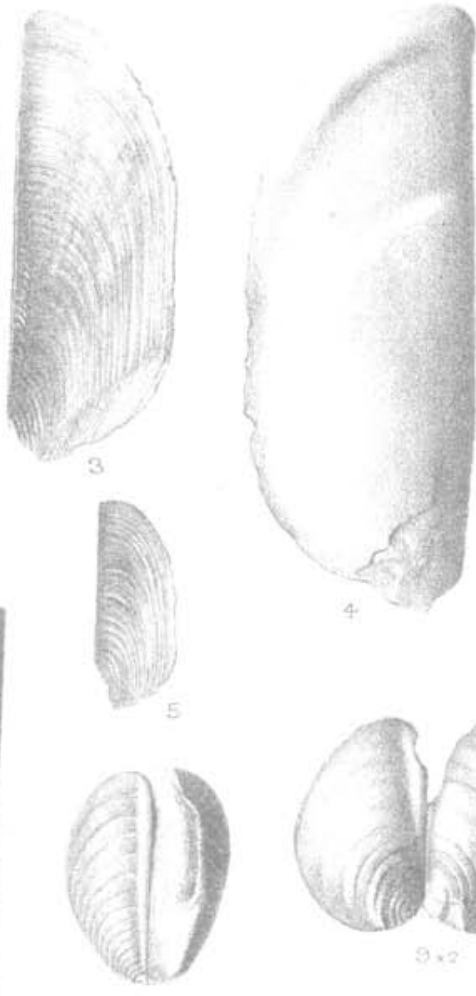

$8 \times 3$

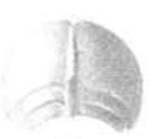

$11 \times 2$
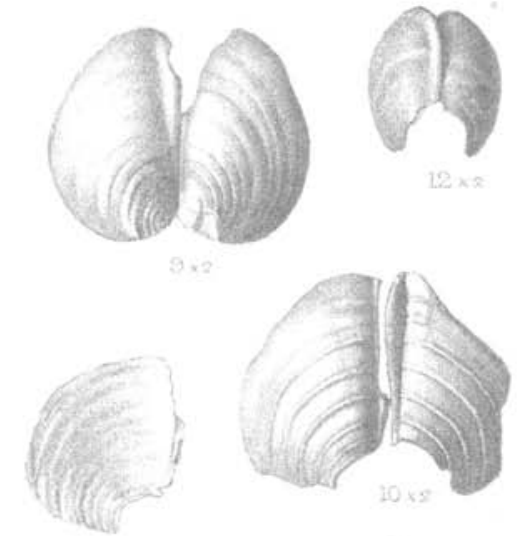

$12 \times 8$

$73 \times 2$

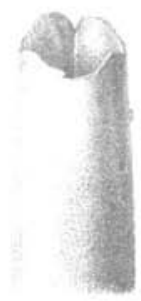

14.

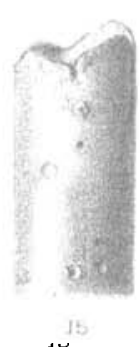

It

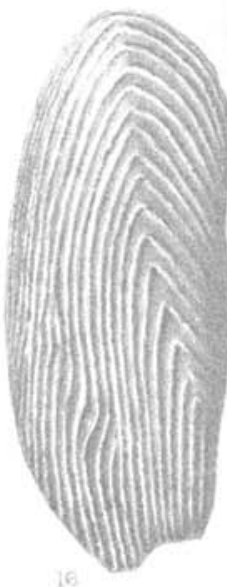

$20 \mathrm{xs}$
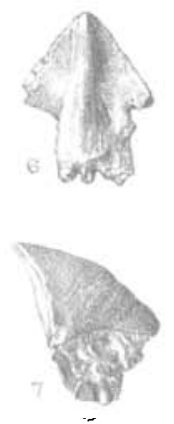

West Nevianan map

Upper Chaik Felernrites. to illistrate îr. H. Biacisurupe's paper 